\title{
FACTORS AFFECTING THE INDIRECT IMMUNOPEROXIDASE STAINING OF INFECTIOUS BURSAL DISEASE VIRUS ANTIGENS IN CELLS
}

\author{
By \\ OKEKE, E.N. and LANG G. \\ Department of Vet. Microbiology \& Immunology \\ Ontario Vet College, University of Guelph, \\ Ontario, Canada
}

\section{SUMMARY}

THE application of the Immunoperoxidase (IP) -dbody technique for the definitive diagnosis of InLotious Bursal Disease (MBD) in chickens has earlier described (Okeke and Lang, 1982). During that - it it was noted that the indirect method of IP was -ore sensitive in the demonstration of IBD viral anbeas than the direct method. Consequently, more information was sought on the specific technical -rimeters and the consequences that resulted by weviations from the codified procedures employed in andirect technique with the alm of obtaining an even better result.

Stadies of $\mathrm{pH}$, serum dilutions, serum incubation -e, conjugate dilutions, conjugate incubation time al developing time were conducted to find out - Hat influence such factors could have on the final ting product.

\section{INTRODUCTION}

Since Coons \& Kaplan, (1950) introduced the immunofluorescence technique (IFT) for the demonstration of cellular particles or antigens, a great deal of progress has been made in immunocytological methods. Fluorescent dyes (Coons, 1959), radioactive substances (Berenbaum, 1959) and heavy metals (Pepe, :961) have been used as markers.

The use of enzymes as markers was ater introduced by Nakane and Pierce 1967), Avrameas and Uriel (1966). In irese techniques the enzyme was first -Present Address, National Vet. Res. Institute, Vom, Nigeria. covalently linked to the antibody, then the enzyme-antibody conjugate was allowed to react with the cellular antigen. The sites of antigen - conjugate reactions were then revealed by cytochemical methods appropriate to the conjugated enzyme.

The standard indirect staining method employed in the demonistration of these antigenic sites was that of Nakane and Kawaoi (1974). In this technique the sections were placed in an airtight box, covered with a specific antiserum and incubated at $37^{\circ} \mathrm{C}$ for 1 hour. The antiserum was removed by rinsing in at least eight changes of PBS was drained and the sections covered with labelled rabbit antichicken IgG and incubated again in a humidified box at $37^{\circ} \mathrm{C}$ for 1 hour. The conjugate was then rinsed in 3 changes of PBS. The PBS was drained and the slide placed in a developing solution for 10 minutes. It was then rinsed in phosphate sucrose buffer, dehydrated in ethanol, cleared in xylene and mounted in DPX mountant.

For the staining of the conjugate in a developing solution the standard staining method involved the use of phosphatesucrosebuffer (PSB) pH 7.4 prepared by mixing $20 \mathrm{ml} 0.1 \mathrm{MKH}_{2} \mathrm{PO}_{4}$ with $80 \mathrm{ml}$ O.1 Mna ${ }_{2} \mathrm{HPO}$. $7 \mathrm{H}_{2} \mathrm{O}$ and adding to it $3.42 \mathrm{~g}$ sucrose (Miller, Karnovsky \& Diamandopoulos 1974).

To $100 \mathrm{ml}$ PSB pH 7.4 was added $50 \mathrm{mg}$ diaminobenzidine (DAB) tetrahydrochloride (sigma chemical). This was kept in the dark and shaken intermitently over $a$

$\because$ zerian Journal of Animal Production 8(1) 1981. 


\section{FACTORS AFFECTING INDIRECT IP STAINING TECHNIQUE}

$30-45$ minute period and then filtered to remove any undissolved DAB. To the filtrate was added just before use $0.03 \mathrm{ml}$ of a $\mathbf{3 0 \%}$ solution of Hydrogen peroxide $\left(\mathrm{H}_{2} \mathrm{O}_{2}\right)$ to give a final concentration of $0.009 \%$ of $\mathrm{H}_{2} \mathrm{O}_{2}$, kept in the dark because it darkens on standing, particularly when exposed to light. The conjugate was allowed to develop in this solution for 10 -20 minutes.

During studies on the IP technique for diagnosis of IBD (Okeke and Lang, 1982), it was observed that the standard staining procedure of Nakane and Kawaoi (1974) did not always produce desirable results. It became necessary therefore to study the various aspects of the staining process in order to determine the optimum conditions for IP staining. In this report, we present the results of studies on the effect of $\mathrm{pH}$, various concentration of reagents, variations in length of incubation and development on indirect IP staining of IBD virus infected cells.

\section{MATERIALS}

Virus strain and antiserum: was Agent 2571 and its anti-serum defined earlier (Okeke and Lang, 1982).

\section{RESULTS}

The following results were obtained as a result of deviations from the codified procedures:- (a) Effect of $\mathrm{pH}$ variations Citrate - phosphate buffer of pH 4.0, 4.5, 5.0, 5.5, 6.0 and 6.5 and phosphate saline (PBS) of pH 7.0, 7.5 and 8.0 were prepared. The infected cell culture monolayers were stained by the standard method for immunoperoxidase staining except that DAB solutions and all washings were done using buffer (PBS or citrate) of the $\mathrm{pH}$ under test. The stained cultures were examined under the microscope and the effect of each $\mathrm{pH}$ level on the staining quality was scored for intensity, clarity and contrast. The $\mathrm{pH}$ level at which only the virus infected cells were stained intensely enough to be observed with ease under the light microscope was regarded as the optimum $\mathrm{pH}$ for staining.

The effect of pH on staining quality is shown in Table 1 . At pH 4.5 and lower the monolayer appeared cloudy and the staining was not specific. AT pH 5.0 to 5.5 stained infected cells could hardly be differentiated from the uninfected cells; the monolayer was hazy and specificity was fair. 
OKEKE and LANG

TABLE *1

The Effect of pH Variations on the Immunoperoxidase Staining of Agent 2571 Infected Chicken Embryo Liver (CEL) Monolayer

\begin{tabular}{lcclc} 
Buffer & $p H$ & $\begin{array}{c}\text { Intensity of Staining } \\
\text { of Infected Cells }\end{array}$ & $\begin{array}{l}\text { Clarity of } \\
\text { Cell Outline }\end{array}$ & $\begin{array}{c}\text { Contrast between } \\
\text { Specific and Backgro } \\
\text { Staining }\end{array}$ \\
\hline $\mathrm{CTT}^{-P_{4}}$ & 4.0 & 0 & Cloudy & None \\
& 4.5 & 0 & Cloudy & None \\
& 5.0 & $1+$ & Hazy & Fair \\
& 5.5 & $1+$ & Hazy & Fair \\
& 6.0 & $2+$ & Clear & Moderate \\
PBS & 6.5 & $3+$ & Very clear & Good \\
& 7.0 & $3+$ & Very clear & Good \\
& 7.5 & $3+$ & Very clear & Good \\
& 8.0 & $3+$ & Very clear & Moderate
\end{tabular}

Legend:

Intensity $3+=$ very dark staining

Intensity $2+=$ moderate staining

Intensity $1+=$ fairly dark staining

Intensity $0=$ no staining.

At $\mathrm{pH} 6.0$ the cell outlines could be clearly discerned, the intensity and specificity were moderately good. From pH 6.5 to 7.5 the cell outline could be seen very clearly and the intensity and contrast between specific and background staining was good. At pH 8.0 the cell outlines were still well defined but uninfected controls stained non-specifically. These observations indicate that for optimum results the correct staining $\mathbf{p H}$ of solutions should not be less than 6.5 but not exceed 7.5 .

(b) Effect of Serum dilutions

Serial fourfold dilutions of the anti-Agent 2571 serum were prepared from 1:4 to $1: 16384$ in PBS, pH 7.4. Each serum dilution was employed separately in the indirect staining of infected
Agent 2751 - monolayers, all other reagents were the same. The highest dilution of serum that gave a specific staining reaction of acceptable intensity and minimum background staining was selected as the optimum dilution in which the serum must be used for best results.

Table 2 shows the effect of antiserum dilutions on indirect IPT staining of cell monolayers infected with Agent 2571. The serum in its undiluted form did not stain as intensely as the 1:2 dilution. The staining intensity was best between $1: 2$ and 1:64 dilutions of immune serum, but decreased progressively thereafter such that at 1:2048 only the unstained, uninfected 
FACTORS AFFECTING INDIRECT IP STAINING TECHNIQUE

TABLE 2:

The Effect of Dilution of Ainti-2571-Serum on the Immunoperoxidase Staining of Agent 257! Infected Chicken Embryo Liver (CEL) Monolayer

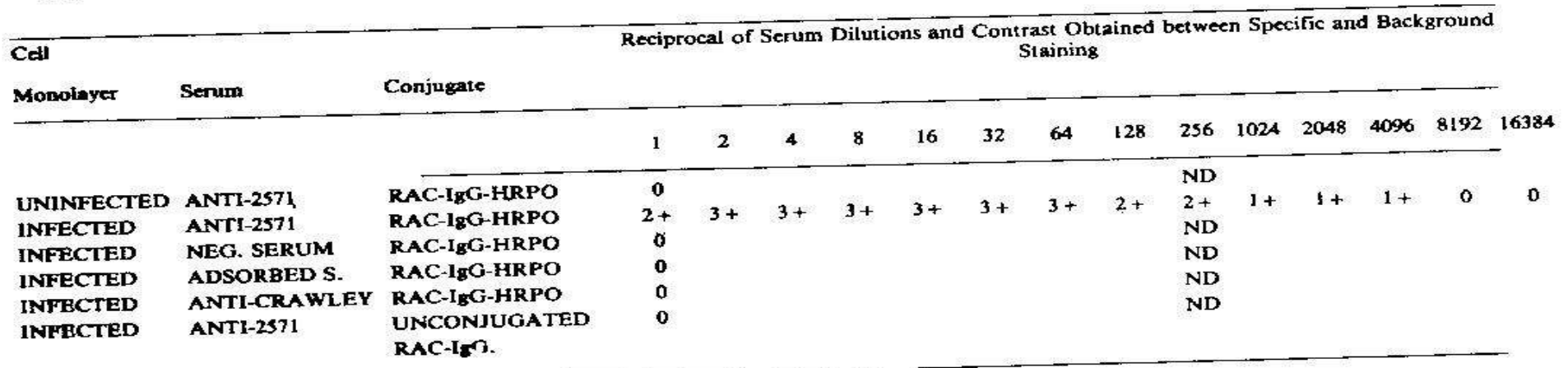

cells could be seen whereas infected cells could no longer be seen in cytopathic areas.

(c) Effect of Serum incubation time

The incubation time after addition of antiserum to the coverslip was studied for periods of 5,10 , $15,20,30,45,60,90$ and 120 minutes at $37^{\circ} \mathrm{C}$ in humid chamber. The results are shown below in tabulated form:

(d) Effect of Conjugate Dilutions

Serial two-fold dilutions of conjugate were prepared from $1: 2$ to $1: 256$ in PBS pH 7.4. Infected cell culture monolayers were stained with the optimum serum dilution (1:64) (Table 2) and then with the conjugate dilution under test, all other reagents remaining constant. The optimum dilution of the conjugate considered best for routin staining procedures was the highest dilutio that gave a specific staining reaction with undiminished intensity and with minimum background staining.

Table 3 shows the effect of conjugate dilutions on the indirect IPT of cell monolayers infected with "Agent 2571." The conjugate could

TABLE 3:

The Effect of Dilution of Rac-lBG-HRPO Conjugute on the Staining of Agent 2571 Infected Chicken Embryo Liver (CEL) Monolaye

\begin{tabular}{|c|c|c|c|c|c|c|c|c|c|c|c|}
\hline \multirow[t]{2}{*}{ Cell } & \multirow[t]{2}{*}{ 1:64 Serum } & \multirow[t]{2}{*}{ Conjugate } & \multirow[b]{2}{*}{0} & \multirow[b]{2}{*}{2} & \multicolumn{7}{|c|}{ Reciprocal of Conjugate Dilutions and Intęnsity of Staining } \\
\hline & & & & & 4 & 8 & 16 & 32 & 64 & 128 & 256 \\
\hline UNINFECTED & ANTI-257I & RAC-IGG-HRPO & 0 & & & & & ND & & & \\
\hline INFECTED & ANT1-2571 & RAC-IgG-HRPO & $3 *$ & $3+$ & $3+$ & $3+$ & $3+$ & $2+$ & $1+$ & 0 & 0 \\
\hline INFECTED & NEG. CONTROLS & RAC-IgG-HRPO & 0 & & & & & ND & & & \\
\hline INFECTED & ANTI-257! & $\begin{array}{l}\text { UNCONJUGATED } \\
\text { RAC-IgG }\end{array}$ & o & & & & & ND & & & \\
\hline INFECTED & ANTI-2571 & $\begin{array}{l}\text { ADSORBED CON- } \\
\text { JUGATE }\end{array}$ & $\mathbf{0}$ & & & & & ND & & & \\
\hline
\end{tabular}


stain up to a dilution of 1:64 (1+) after which the staining ability was bst. The intensity of background staining faded gradually with the conjugate dilution, but the full staining intensity of infected cells remained the same $(3+)$ up to a dilution of 1:16, after which it was slightly reduced $(2+)$. Bursal sections and infected cell culture monolayers were satisfactorily stained at this 1:16 dilution of the conjugate.

(e) Effect, of Conjugate incubation time: Infected Coverslips were first incubated with specific anti-serum

After washing off residual serum thoroughly in several changes of PBS, pH 7.4, coverslips were

TABLE 4:

Serum Staining Time:

Incubation

$5-15$

$20-25$

$30-60$

90

120
Time Observation:

Specificity of

Staining

minutes Poor

minutes Fair

minutes Good or Excellent. Little background Staining

minutes Poor. Increased background staining

minutes Very Poor. Extensive nonspecific staining of uninfected cells. covered with the conjugate at 1:16 dilution and incubated for $4,10,15,20,25,30,45,60,90$ and 120 minutes at $37^{\circ} \mathrm{C}$ in a humidified chamber. The following staining results were obtained:

TABLe 5:

Conjugate Staining Time

Incuba tion

Time Observation:

Specificity of Staining

5-15 minutes

Poor. Infected cells cannot be differentiated from uninfected cells

$20-25$

minutes

Fair. Infected cells begin to stain faintly

$30-60 \quad$ minutes

Good. Little background staining

$90-120 \quad$ minutes

Poor. Too much background staining. 
(f) Effect of Hydrogen peroxide $\left(\mathrm{H}_{2} \mathrm{O}_{2}\right)$ concentration

Hydrogen peroxide was purchased as a $3 \%(\mathrm{~W} / \mathrm{V})$ solution in water. Dilutions were prepared from the stock solution to produce $0.3,0.15,0.05,0.02,0.1$, 0.005 and 0.0005 per cent $\mathrm{H}_{2} \mathrm{O}_{2}$. The effects of the different concentrations of $\mathrm{H}_{2} \mathrm{O}_{2}$ on the staining intensity and specificity of IP - staining were studied.

The results showed that increasing concentration of $\mathrm{H}_{2} \mathrm{O}_{2}$ progressively increased the intensity but decreased the specificity of staining. The $0.01 \%$ concentration of $\mathrm{H}_{2} \mathrm{O}_{2}$ was regarded as optimum for the staining procedure.

(g) Effect of Developing time

Virus infected tissue were incubated in the presence of DAB containing $0.01 \% \mathrm{H}_{2} \mathrm{O}_{2}$ for 5,10 , $15,20,25,30$ and 60 minutes and the staining intensity and specificity was studied for each preparation. The incubation was done at room temperature and in the dark to prevent the effect of light on DAB. The results indicated that sections could be incubated in the developing solution for up to 20 minutes without any significant change in the staining specificity. At 5 minutes normal controls began to show some darkening which became most intense after 60 minutes. The optimum staining intensity was attained at 10 minutes incubation.

\section{DISCUSSIONS}

The routine application of a diagnostic test requires also that it can be reliably carried out by laboratory technicians. The IP-test does not demand very critical ex- perimental parameters, except the necessity of a good, monovalent specific antiserum. The functionally acceptable $\mathrm{pH}$ range of 6.5 to 7.5 is wide. Hanon, et al (1975), Eckert \& Simpson (1975) prefer to work in the acid (pH 6.8), while Miller, et al (1974) recommend alkaline (pH 7.5) conditions. The present study indicates that $\mathrm{pH}$ is notcritical, and acceptable specificity can be obtained between $\mathrm{pH}$ 6.5 and 7.5: The dilution of the anti-viral serum will not affect the diagnostic interpretation of the staining if carried out moderately beyond the optimum range; only the staining intensity will be reduced. The use of antiserum of dilutions up to 1:64 and higher increased the quality of staining by reducing the background staining considerably so that infected cells alwlays stained much darker than noninfected cells. As with other serological procedures, the use of undiluted serum affects the test results by an excess of nonimmunological proteins, which tend to overshadow the specific immune complexes. Similarly the serum incubation time of $\mathbf{4 5}$ minutes is very practical for daily routine and still leaves enough flexibility ( \pm 15 minutes) without annoying consequences. This study indicates that serum incubation time can be shortened to 30 minutes with excellent result.

The optimum conjugate dilution has to be determined for each batch, but the diluted conjugate was stable for at least six months when stored at $-20^{\circ} \mathrm{C}$ and at $4^{\circ} \mathrm{C}$ for a day, but no attempts were made to use the diluted conjugate on subsequent days. Refreezing of the diluted conjugate is not recommended and was found to be detrimental to the test in this study. The conjugate was best used at a dilution of $1: 16$ for 45 minutes at $37^{\circ} \mathrm{C}$.

The concentration of $\mathrm{H}_{2} \mathrm{O}_{2}$ in the developing reagent was routinely $0.01 \%$, a value close to the upper limit of the range established in this study $(0.0005 \%$ to $0.02 \%$ ) and within the range of 0.005 to $0.05 \%$ of Weir, Pretlow, Pitts and 


\section{OKEKE and LANG}

Hilliams (1974), of 0.006 to $0.02 \%$ given zy Nakane and Yasuda (1975) and 0.075 $: 0.188 \%$ for the enzyme assay ¿eveloped by $\mathrm{Lyr}(1975)$. Excess of $\mathrm{H}_{2} \mathrm{O}_{2}$ is said to cause reaction with tissue hemeenzymes other than peroxidase (Berenbaum, 1959).

The developing time of the staining of $10-30$ minutes is a wider value than the ecommendations of Nakane and Kawaoi, (1974) of $10-20$ minutes. Weir et al, Pretlow, Pitts and Williams. (1974) preferred to incubate sections first in DAB alone for 30 minutes then for 2 minutes in DAB with $\mathrm{H}_{2} \mathrm{O}_{2}$. This modification was not found better than the original method of Graham and Karnovsky, (1966).

\section{REFERENCES}

AVRAMEAS, S. \& URIEL, J. (1966).

Methods de marquage d'antigenes et d'anticorps avec des enzymes et son application en immunodiffusion. C.R. Acad. Sci. (Paris) 262; 2543 - 2545.

BERENBAUM, M.D. (1959). The autodia graphic localization of intracellular antibody. Immunology $2 ; 71-83$.

COON, A.H. \& KKAPLAN, M.H. (1950).

Localization of antigens in tissue cells. Jour. Exptl. Med. 91; 1.

CoONS, A.H. (1956). Histochemistry with labelled antibody Int. Rev. Cytol. $5,1-23$.

GRAHAM, R.C. \& KARNOVSKY, M.J.

(1966): Glomerular permeability. Ultrastructural cytochemical studies using peroxidase as protein tracers. $\mathrm{J}$. ExptI. Med. 124; 1123.

HANON, N.J., ECKERT, H.L. \& SIMPSON, J. (1975). Assessment of virus infectivity by the immunofluorescent and im- munoperoxidase techniques. Jour. Clin. Microbiol. 1, 324-9.

LYR, H. (1957): Ein neues peroxydase-

Bestimmungsverfahren Biochem. Z.329: 91.

MILlER, M.H., KARNOVSKY, M.I. \& DiAMANDOPOULOS G.Th. (1974): An improved immunoperoxidase technique for identifying SV40 virus and T. antigens by light microscopy. Proc. Soc. Exptl. Biol. Med. 146: 432 - 437.

NAKANE, P.K., \& PIERCE, G.B. (1967):

Enzyme labeled antibodies for the light and electron microscopic localization of tissue antigens. Jour. Cell. Biol. 33, $307-318$.

NAKANE, P.K. \& KAWAOI, A. (1974):

Peroxidase labeled antibody. A new method of conjugation. Jour. Histochem. Cytochem. 22, 1084 1091.

NAKANE, P.K. \& YASUdA K. (1975):

Recent progress with peroxidase labeled antibody method. Acta Histochem.

Cytochem. 8: $30-39$.

OKEKE, E.N. \& LANG, G. (1982): The application of the Immunoperoxidase (IP) antibody technique for the etiological diagnosis of infectious bursal disease (IBD) in chickens. Nigerian Jour. Anim. Prod. 8: No. 1.

PEPE, F.A. (1961): The use of specific antibody in electron microscopy. Preparation of mercury labeled antibody. Jour. Biophys. Biochem. Cytol 11, $515-520$.

Weir, E.E., Pretlow, T.G., Pitts A., \& Williams, E.E. (1974): Destruction of endogenous peroxidase activity in order to locate cellular antigens by peroxidase labelled antibodies. $J$. Histoche. Cytochem. 22: $51-54$. 